POLITYKA ENERGETYCZNA - ENERGY POLICY JOURNAL

$2021+$ Volume $24 \diamond$ Issue $2 \nrightarrow 57-78$

DOI: $10.33223 / \mathrm{epj} / 136038$

Oksana D. Hnatkovych ${ }^{1}$, Volodymyr V. Hoblyk $^{2}$, Olena V. LaZarieva ${ }^{3}$, Vasyl V. Burba ${ }^{4}$, Yevhenii Ye. HrechiN ${ }^{5}$

\title{
Regulation aspects of development and the use of energy resources in the transboundary zones by international business
}

ABSTRACT: The article presents aspects of the legal characterization and regulation of the natural resource's treatment that are under the joint tenancy of two or more states. The scientific novelty of the study is determined by that fact that shows the aspects of international interaction and the formation of the practice of legislative regulation of the use of natural resources, not only in the field of state and legal regulation but also within the context of private-public partnership. The relevance is determined by the fact that the main problem of the development of energy resources is an opportunity

$\triangle$ Corresponding Author: Oksana D. Hnatkovych; e-mail: hnatkovych5909@unesp.co.uk

1 Department of Culture and Arts, Ivan Franko National University of Lviv, Ukraine; ORCID iD: 0000-0002-5447-2551; e-mail: hnatkovych5909@unesp.co.uk

2 Department of Management and Economic Processes, Mukachevo State University, Ukraine; ORCID iD: 0000-0003-1793-833X; e-mail: v.hoblyk5909@kpi.com.de

3 Department of the Landed Resources Management, Petro Mohyla Black Sea National University, Ukraine; ORCID iD: 0000-0002-1050-7118; e-mail: lazarieva5909@national-univesity.info

4 Department of Anti-Corruption and Combating Organized Crime, National Academy of Security Service of Ukraine, Ukraine; ORCID iD: 0000-0001-5680-9923; e-mail: v-burba5909@murdoch.in

5 Department of Anti-Corruption and Combating Organized Crime, National Academy of Security Service of Ukraine, Ukraine; ORCID iD: 0000-0002-5751-3945; e-mail: hrechin5909@uoel.uk

2021. The Author(s). This is an open-access article distributed under the terms of the Creative Commons Attribution-ShareAlike International License (CC BY-SA 4.0, http://creativecommons.org/licenses/by-sa/4.0/), which permits use, distribution, and reproduction in any medium, provided that the Article is properly cited. 
to determine and accordingly implement certain provisions for international business enterprises. The purpose of this article is to study the question of how representatives of international business can implement projects for the extraction of natural resources across boundary areas and under various conditions within the framework of cross-border cooperation. In the work, the methods of mathematical statistics, historical and legal methods were used. A three-level model was presented. This model determines the possibility of ensuring cooperation, then it forms its legal and regulatory framework and then determines instruments of an economic and legal nature that can be implemented in this field. The final point of the model is the finding of opportunities for investing in the development of natural energy resources on a parity basis, as well as the formation of an integrated environment that determines the possibility of integrating the subjects of international business into the economic environment of the state.

KEYWORDS: cross-border cooperation, ecosystem, resource management, concession, attracting foreign direct investements (FDI)

\section{Introduction}

Within the sphere of cooperation between states in matters of business, the leading role is played by the process of presenting opportunities for obtaining the resources from which an economic product is formed. The basis for everything is the extraction of subsoil resources, which often occur on the territory of various states. If the point at issue is that the state owns a resource that is classified as renewable and extremely non-unique, such as water or solar irradiation, then each state will be a user of the same resource in full accordance with the understanding and natural resource management policy. In some cases, the border resource is physically impossible to develop by the efforts of only one country. After all, the development of natural resources is a technological cycle, which is based on the fact that it requires technological, legal and economic measures. The most important measures are the technological ones, which show that in the modern technological world race the most important are world-class technologies. Therefore, it is necessary to talk about the need for the presence of international business structures. So, this forms a certain sequence of how it is necessary to interact between all its subjects.

Up to date, hot issues of international law are uncoordinated aspects relating to the legal definition of the status of transboundary natural resources (Ali and Zia 2017). Sometimes the last-mentioned are the subject of disputes and conflict situations arising between bordering countries. Not in every instance, a negotiation process and good-neighborly relations between states facilitate a solution to such problems (Degefu et al. 2016). Therefore, it is important to promote the implementation of the international legal regulation of issues that will remove obstacles in this field. The above-mentioned problems were the subject of study (Carr 2017). Some aspects were considered in the works of Giordano et al. (2016), He et al. (2017). The works by Li et al. (2016), Schiff (2017), in which the indicated problems were covered are among the authors of particular note. 
Earle and Neal (2017) make a point at a comprehensive scientific study of issues relating to the legal regime of natural resources that are located in territories with different legal status. Mason et al. (2017) explores various aspects of cross-border cooperation, namely: ecological, socioecological, economic and legal aspects. For the sustainable management and monitoring of the use of transboundary resources, providing an effective mechanism for cross-border cooperation is necessary (Mason et al. 2020). Pétré et al. (2016) defines the main problems of transboundary environmental and economic cooperation in the sphere of water resources use and protection. Rai et al. (2017a, 2017b), Al-Faraj and Tigkas (2016) examine the regional aspects of the protection of environmental waters and the prerequisites for improving the economic mechanism of water management. Singh (2016) conceives that the most effective approach to water management is integrated water resources management. Tang et al. (2016) explores the management of water protection activities.

Therefore, outside the field of view of national researches there are such types of transboundary resources as transboundary ecosystems and transboundary mineral deposits requiring more detailed consideration. The study of ecosystem transboundary resources is determined by the possibility of identifying their entropic parameters (Bolgov et al. 2016; Holmatov et al. 2016). Increased understanding of the transboundary use of natural resources is defined in the field of fossil fuel use and related issues of operation management (Akhundjanov and Muñoz-García 2019; Lim 2016). This approach is determined by the fact that fossil fuels are becoming the most important element that acts as an institutional norm of regulation and formation of investment attractiveness and allocation of special benefits for the company, as often more than $70 \%$ of all technological equipment is purchased from representatives of international business (Healy et al. 2019). Hence, it is about the formation of a new market.

Also, the authors examine the process of understanding of transboundary resources and business interests in the sphere of providing an ecosystem approach and a political field of research, namely human rights. Commonly, this process is typical for the territories of Africa and generally developing countries (Carr 2017). At the same time, a level assessment and the formation of a qualitative assessment of the state of the habitat for developed countries are proposed (Madani 2020). Also, international business and the transboundary structure of food security are closely interrelated. These primarily include commercial cultures and the use of fauna objects (Thornton et al. 2020). Attempts are being made to limit consumption at the level of interstate cooperation, when not only the border areas are projected as an object of business, but the ecosystems of all states as an object that has influence and impact on the territory of an integrated region (Barbakov et al. 2019).

A separate unit in international business is defined as a service object. International business cannot only extract resources, but also perform monitoring of their condition. This is especially true for countries that have only taken the path of transit to a more environmentally sound policy (Hashemolhosseini 2020). Also, here the authors include those structures that should directly determine the possibility of modern choice and, accordingly, informatization and justification on economic models of the path chosen by the authorities to improve the efficiency of the functioning of the entire environment at large (Booth et al. 2020). 
The need to find a synergistic effect and all applicable methods is the subject of this article. The purpose of this article is to study the question of how representatives of international business can implement projects for the extraction of natural resources across boundary areas and under various conditions within the framework of cross-border cooperation. Accordingly, the following tasks are set: to determine the main features of "transboundariness", to substantiate the relevance of transboundary management of natural resources and to identify the main factors that affect the state of technological, economic and legal context.

\section{Materials and methods}

In the work, the methods of mathematical statistics were used to calculate the model, which shows the basis for increasing the attractiveness of the territories of states for the resource development. The historical method determines the possibility and geographically differentiates the regions according to the degree and extent of cooperation in the frontier areas. The legal method determines the basis for the assignment and the separation of the products.

The modern world is characterized by two regular and objective processes, the essential characteristics of which result from the occurrences of regionalization and globalization of the world economic and social space. A peculiar indicator of these processes are borders as specific territorial and spatial entities that, on the one hand, differentiate the political and cultural landscape of individual states, and on the other, are zones of contact interactions between political-administrative entities in the global space (Reynolds 2019). Global transformational and geopolitical changes that occurred at the end of the $20^{\text {th }}$ century, show that in the modern world, the borders have become more transparent and permeable than they were half a century ago, and over the past twenty years more borders (especially in Europe) have appeared than during the previous half-century.

In modern political geography and geological thought, several consecutive theoretical approaches have been identified in the study of boundaries, which can be combined into two groups traditional and postmodern. Modern postmodern approaches consider borders as lines of contact and zones of interaction between individual states, and the frontier regions, which mainly had features of deep country-side, in the modern sense, are understood as locomotives of economic growth based on the formation of various forms of cooperation on the principles of finding a balance between border security and the development of cross-border cooperation, the interests of central leadership and frontier areas. This is an indication that today the border is less restrictive, at the modern stage it is a place of meeting, cooperation, neighborhood and partnership. A special role in the development of processes of cross-border cooperation belongs to the creation of cross-border regions, which are a union of nearby administrative-territorial units of different hierarchical levels of neighboring countries that have direct access to the state border (Tilleard and Ford 2016). Particularly, in the Western European regional practice, the Euroregions are legally registered cross-border regions in which cross-border cooperation is carried out. 
In the Western Europe in the 1960s, the concepts "Europe of Regions" and "New Regionalism" were formulated. The corresponding concepts were premised on vesting the regions within the European Union with broad powers; regions have been entitled to enter various relations with other regions, to unite in groups of regions, to interact with them and separate states, going beyond the borders of national states. One of the directions for regional development activation, and exploiting advantages of the polarity and regional disparities that have developed on the basis of the previous paradigm of the existence of a united Europe in the form of national states, is cross-border cooperation between regions that are directly adjacent to the state border, which are institutionalized in the form of Euroregions. Euro-regional development, based on cross-border cooperation within the EU, is aimed at eliminating psychological barriers of privacy, overcoming prejudices of national identity, and, according to the representatives of the Association of European Border Regions, brings European added value, which manifests through socio-economic, political, institutional and sociocultural added values. Now, within a unified Europe and its neighboring countries, there are 185 functioning and prospective Euroregions, corresponding financial mechanisms and institutions have been created: the European Regional Development Fund, the Cohesion Fund, the European Social Fund, which finance selected regional programs and projects (PHARE, TACIS, CARDS, MEDA and others). For the implementation of cross-border initiatives within the European Union and cohesion policy, the INTERREG III A program is in operation, and its goal is the development of joint border regions of two or three states (NUTS III level), the formation of socio-economic growth points in these regions based on joint development strategies.

The main areas of program support are the development of towns and villages; development of enterprises; development of small and medium-sized businesses; development of human resources (abilities, culture, health, education, communications, social sphere); environmental protection, energy use and saving; development of transport, communication and information networks; repair of water and electricity networks; legal and administrative cooperation; development of human resources and institutions to promote cross-border cooperation. In order to coordinate the efforts of participants in cross-border cooperation, exchange of experience, coordination of joint projects, the Association of European Border Regions was created (1971). The logic of the functioning of state borders in North America is primarily connected with the economic intentions to ensure the permeability of borders for goods and services, gaining mutual benefits from the abolition of customs duties and taxes, as well as quantitative restrictions in mutual trade, which was embodied in the creation of the North American Free Trade Zone between the USA, Canada and Mexico. Trade unity within NAFTA does not aim to create a "North American identity", in North America there are no specialized structures to promote cross-border initiatives, such as INTERREG or the Association of European Border Regions. Cross-border cooperation is carried out on two borders: between the US and Canada, the US and Mexico.

The high degree of border interaction between the United States and Canada is related to the general historical and cultural development of these countries and economic integration that has evolved over the decades. The transparent nature of the border creates natural preconditions for 
the implementation of cross-border socio-economic initiatives. Appropriate initiatives are presented in the border regions between the US and Canada, which are provincial or state groups that stretch along the 49th parallel, on the basis of economic and organizational links within the four transboundary regions: Western, or Cascadia (Alaska, Washington, Oregon, Idaho, Montana; Yukon, British Columbia, Alberta); Steppe, or Great Plains (Montana, Wyoming, North Dakota, South Dakota, Minnesota; Alberta, Saskatchewan, Manitoba); Major Lakes - Heartland (Michigan, Indiana, Ohio; Ontario); East (Vermont, Manchester, New Hampshire, New York, Massachusetts, Rhode Island and Connecticut; Quebec, Atlantic Canada). All cross-border regions interact in three directions: economic (creation of border clusters, accumulation of capital through border maximization of benefits), organizational-institutional and sociocultural; the depth and priority of links in all regions is different.

One of the resources for the development of border regions along the US-Mexican border are free economic development zone - maquiladoras, which are export-production areas with preferential business practices using cheap labor, energy and low transportation costs in the Mexican border states. These zones include industrial enterprises (consumer goods manufacturing, motor vehicle industry, electrical and electronic equipment), which are engaged in the production of goods and services for export based on the processing of foreign materials coming in reverse import mode. Most of these enterprises were confined to a 20-kilometer strip along the Mexican border, which stimulated the development of twin cities (San Diego-Tijuana, El Paso-Ciudad Juarez, Laredo-Nuevo Laredo, Brownsville-Matamoros) and provided an opportunity to take important steps in development of border social and economic infrastructure: the creation of centers for the adaptation of migrants, new jobs, cooperation in the education field (the establishment of training centers, student exchange, co-educational programs, mutual recognition diplomas) and others.

In Latin America, cross-border cooperation is carried out mainly within the main Latin American integration entities, such as the Central American Integration System, the Andean Commonwealth of Nations and the Common Market of the Countries of South America (MERCOSUR). Corresponding border initiatives are implemented with the support of foreign entities (for example, the EU, through the Spanish Agency for International Cooperation, supports the "Open Borders" project, selected US projects through financial instruments of the Inter-American Development Bank, etc.). Such actions as those defined in the Open Borders program are based on the belief that the creation of translocations contacts through border cooperation can contribute to the idea of borders not as barriers that impede movement and development, but as bridges connecting neighboring countries and ensuring economic growth and development.

The Central American Integration System assumes the use of state borders between states to build a system of interrelations between participants of integrational education based on the promoting a cross-border cooperation between the neighboring regions of the participating countries by providing integrative programs and arrangements. Particularly, the Tripartite Plan (El Salvador, Guatemala and Honduras) should contribute to the creation of viable agricultural models, increased cross-border contacts between the border administrative units of the three countries, the establishment of public organizations of farmers, teachers, various associations 
and development objects, joint management of water and agro-resources (Salmoral 2019). The project of cooperation between Panama and Costa Rica intends the maximizing of cross-border cooperation for local development and the organization of a continuous flow of tourists in the border areas of both countries; the construction of a high-speed highway between Juigalpa (Department of Chontales, Nicaragua) and the border with Costa Rica to strengthen regional trade, integration, unification of economic regions and rapprochement of the two countries of the Caribbean region.

The Andean community has adopted a unified policy on cross-border integration and development, which intends the functioning of two tools for the rapid implementation of border development - border integration zones and binational border service centers. The border integration zones are border areas that are adjacent to the states parties to the Andean Community. Their projects are carried out to support development through the unification of common and coordinating actions: the cooperation of social parties, entrepreneurs, workers, private organizations and civic associations; stimulation of local, national, binational and foreign private investments, exchange of initiatives between local administrations and regional development organizations. Up to day, the border integration zones operate on the borders between Colombia and Ecuador, Colombia and Peru, as well as Bolivia and Peru.

Binational border service centers are local entities on the territory of one or two contiguous countries of the Andean community, near the border crossing with the integrated control of the flow of people, baggage, goods and vehicles, combined with additional assistance and customs services. Binational cooperation on the border between Brazil and Uruguay is aimed at implementing several projects in the field of infrastructure improvement, construction of transport highways, railways, bridges, etc. At the same time, cross-border cooperation between Uruguay and Brazil in the border regions is carried out through the organization of free trade zones and the provision of border citizenship to the residents of these regions, which ensures the free movement of people, goods, services and capitals, easier border and tax control, joint customs administration in border inspection posts, exemption from taxes, simplification of trade, exclusion of double tax for city residents, cultural integration, etc.

The most expressive form of cross-border cooperation within the framework of MERCOSUR are twin cities located on both sides of the border. They unite large isolated cities and regions with insignificant economic activity, stimulating the development of the local economy through a simplified regime for obtaining licenses for the export (import) of goods and services, creating preferential terms for small and medium businesses, implementing projects with border management, education, social protection, energy infrastructure, culture, construction, sustainable tourism, innovation and business centers, etc. Cooperation between the border twin cities is common on the borders between Uruguay and Brazil (12 cities), Uruguay and Argentina (8 cities), Argentina and Brazil (24 cities), Brazil and Paraguay (10 cities), Argentina and Paraguay (12 cities). The Asia-Pacific region has developed such integrations as triangles of growth, which are transnational economic zones (two or more countries) with clear boundaries. Such entities, where there is a free movement of labor, capital, and technology, are also called natural economic territories or sub-regional economic zones. 
Triangles of growth unite the neighboring regions of the countries separated by borders with the unlike factors of production (land, labor, capital, labor, technology, administrative and managerial skills) and various sources of comparative advantages for the formation of sub-regional economic growth, the distribution of the corresponding benefits to less developed areas of national economies. This growth is provided by the private sector, but with the support of government cooperation that eliminates barriers to production factors and goods. The main economic mechanism that creates benefits is the economies of scale, namely a combination of fund factors in different locations (industry in some parts of the sub-region may have advantages in technology, and knowledge is available in others); savings in the distribution of marketing, financial and business services; savings in civil infrastructures, such as: utilities, transport infrastructure, telecommunications, energy, and water supplies. Triangles of growth were considered by many nations-parties in ASEAN as a unique Asian solution to the problems of achieving regional economic integration between countries at different stages of development. Now, within the Asian growth triangles, there are 8 triangles of growth that cover the adjacent territories of 15 countries of the region.

The ideas of the new regionalism have also penetrated with the countries of Africa, particularly, the Declaration on the African Union Border Program emphasizes the need to overcome borders as barriers and to consider them as bridges that unite one state with another, to integrate the African continent, create a strong alliance for peace, safety and stability through structural conflict prevention. The active processes for the implementation of cross-border cooperation are observed within West Africa. They are carried out with the support of the European Union and the use of experience of history, methods, and practices of EU integration processes. Among the promising areas of cross-border cooperation within West Africa, the following can be identified: territorial planning; economic development of border regions based on the use of the "border effect"; tourism; development of transport and infrastructure.

\section{Results and discussion}

An active form of the corresponding regionalism is presented by the development corridors, which are transport or trade corridors with insufficient use of the economic potential of neighboring states. They are considered as means of planning and promoting of interconnected infrastructure and large-scale economic sector investments in various geographic areas, they are activating trade and investment, providing economic growth, optimizing the use of infrastructure, stimulating value-added processes, and improving the competitiveness of the African economy in the regions and on the continent. Relevant development corridors are very actively represented within South Africa. For example, the Maputo Development Corridor is based on the activation of the axis between the economic heart of South America - Gauteng and Mpumalanga (the province of South Africa) and the port city of Maputo (Mozambique). 
The main forms of organizational and economic relations of subsoil use, according to which foreign investments are attracted, are the following: concession form of organizational and economic relations of subsoil use; licensing form of organizational and economic relations of subsoil use; production sharing agreement; service contract (Nałęcz and Puri 2012). A representative of the state is often a national company. However, in recent times an increasingly important role in relations with a foreign investor has been played by relevant state bodies. This stems from the fact that the national companies of many countries cease to be completely controlled by the state through privatization processes (Great Britain) and, in part, through increasing the share of private capital in these companies (in the Netherlands, in Sweden). However, in developing countries, a mandatory condition for legislation or a contract can be the establishment of a joint venture between an investor company and a state mining (oil) company.

The above-mentioned forms of attracting FDI into the industry have significant discrepancies. Let's consider each of them separately. So, the concession is the result of an agreement on the handover to production for a certain period of natural resources, enterprises and other economic objects owned by the state. This is the scheme of relations between the state and, commonly, a foreign investor (company), which is approved by the contract (sometimes the relevant act of state under the current legislation). It is important that the right to develop the deposit differs from the ownership of land or mineral wealth. This form does not presuppose the granting of ownership, but is an administrative law, is stipulated by specific conditions, is limited in time and in certain circumstances may be canceled. In more detail this is defined in the mining codes. In modern concessionary form, an important role is played by relations between the state and companies, enshrined in legislation and formed within the process of a market economy developing. The granting of rights (permits, licenses) related to the use of natural resources, as well as the further activities of the owner of these rights, is governed by mining legislation, or by industry-specific laws, for example, oil and gas legislation. With well-developed legislation, this form allows all subjects to be placed on an equal footing before the law and to exclude the possibility of providing advantages to any company.

On the other hand, without sufficiently developed legislation regulating both the relations of the company and the state, and the relations between companies (single risk, unified agreements), contracts in each case acquire special features and can prevail over the law. The main features of the concession include: the entity that owns the concession is granted ownership of the extracted products during the discovery and development of the deposits; the subject who owns the concession is entitled to free use of land and mineral wealth; the subject that owns the concession remains the owner of the equipment that was used by him during the works; the tax regime is the economic basis of the concession agreement, which includes the payment of royalties and income tax.

In the international practice, there are three main options for state participation for such a form of attracting FDI into the industry (through state bodies or through a national oil company): 1) with the "transferred state participation" - first the foreign company finances the entire project, and then the state proportionally reimburses the costs from the share of the products it receives (in this case this form has several features in common with the PSA); 2) by direct 
financing; 3) without financing. Over time, this form, which is sometimes called "traditional concession", has undergone significant changes and evolved into a licensed form. The licensing form of attracting FDI to the industry is common in more than 50 countries.

The overwhelming majority of Western European countries use this type of transactions not only in general terms similar to concession ones, but also in a "modernized" way. So, if earlier the state did not have sufficient levers of influence on the activities of foreign companies under the concession form, today state bodies can regulate this activity through exploration and development programs and pilot development programs, the operational development projects should be presented by mining enterprises at different stages of work and agreed with the relevant government agencies or with the national oil company, the implementation of which is obligatory under current legislation (mining codes, laws). The licensing system is a certain system of rights, the main one of which is the right to explore or develop natural resources for a strictly limited period of time and on the conditions fixed in the license. Commonly, such conditions include the following: 1) return of land plots; 2) minimum working liabilities of a foreign company; 3 ) payments for land and subsoil use; 4) state participation in decision-making (Nałęcz and Puri 2012).

The analysis of the experience of many countries around the world about the choice of a licensing form for attracting FDI into the industry allows the authors to conclude that the current system of licenses is very effective for the state, but only under the condition of stability of mining and tax legislation. In this case, it can provide more reliable guarantees of both compliance with national interests and investor rights. A feature of production sharing agreements is the provision of a contract to the force of law. This is one of the reasons for the wide spread of this form of attracting FDI to the industry in countries that are only developing. The agreements on the division of production in the world practice contain, as a rule, the following basic elements:

$\checkmark$ partial distribution is the economic basis of the PSA;

$\checkmark$ according to the PSA, all the distribution products belong to the state (this fact is very important, considering the opportunities provided by this feature for market regulation);

$\downarrow$ the mining company is a contractor who has a contract for work;

$\checkmark$ the mining company is responsible for all costs and all risk;

$\checkmark$ recompense of costs from the share of the investor's products (in most cases);

$\checkmark$ it is possible to apply royalty payments to the PSA in some cases;

$\checkmark$ the "autonomy" of the tax and legal regime is inherent for the PSA;

$\checkmark$ equipment that was used by the contractor becomes the property of the state after the recompense of its value to the contractor;

$\checkmark$ the contractor is obliged to fulfill the minimum compulsory work program at each stage (prospecting, exploration, development);

$\checkmark$ the contractor is reimbursed all costs in accordance with the special accounting procedure. In contrast to the widespread accounting of costs, this occurs as part of the cost of production as a sum of running costs and depreciation. In this case, the accumulated amount of current and capital expenditures is presented for reimbursement. The advantage of the PSA is a simple and effective mechanism for withdrawing the state share of revenues. Service contracts are a specific form of participation of foreign companies in the development of natural resources. 
They contain elements of a concession agreement, and a production sharing agreement. This form is most developed in Latin America (Chile, Brazil, Peru, Ecuador). Distinctive features of service contracts are that the company takes all risks and all expenses at the prospecting stage. In the case of a commercial discovery, the company receives a recompense, but not in the form of a product, and usually in cash. The amount of the recompense depends on the value of the extracted resources.

A joint venture (JV), created with the participation of state and private companies, commonly, does not differ in legal status from an enterprise with $100 \%$ participation of private companies. Such a JV is an association of companies for the purpose of joint participation in a project, for carrying out activities under the terms of a license form or under the terms of a production sharing agreement. A joint venture, created with the participation of a state company both within the concession and within the framework of the PSA, is an important element of this relationship. The purpose of such a joint venture is the participation of the state in the project not only as the owner of mineral resources, but also as an investor.

In turn, joint ventures created with state-owned companies are divided into three main categories:

1) the participation of a state-owned enterprise is carried out in the form of investments (deposit of financial resources or fixed assets) on terms that are typical for a foreign company;

2) the participation of a state enterprise takes place in the form of a so-called "transferred interest" or, in other words, "deferred participation". In this case, at the first stages of exploration, the foreign company takes over all financial and geological risks, and after the discovery of the deposit and the start of production, the state enterprise reimburses from its share of profits the expenses of the foreign company in proportion to its share of participation;

3) the participation of a state enterprise takes place in the form of the realization of the rights of the state as the owner of resources. In this case, the enterprise's contribution is intangible assets, which include the value of the rights to use mineral, land, water and other natural resources.

A joint venture with a state-owned enterprise is established under a concessionary form of activity (Guinea-Bissau, Nigeria), but in several countries, such joint ventures perform the role of contractor in the production sharing agreements (Angola). An analysis of world experience has shown that foreign direct investments attract not only oil-producing developing countries but also developed states of Western Europe, like Great Britain and Norway. The development of oil and gas deposits in the North Sea that was discovered in the sectors of these countries, was conducted with the involvement of American and German capital and contributed not only to the growth of monetary incomes but also to the strengthening of the energy economies of these countries. True, once-weak, but for today the powerful energy complex of Great Britain have begun to develop intensively since the mid-1970s during the development of the resources of the North Sea, largely based on American technology and American capital. External inflow in a short time helped to master innovative approaches and the latest technologies.

That is why in the early 1980s in the UK, the problem of energy self-sufficiency was solved. In Norway, until the discovery of the first deposits, there was neither own experience, nor oil and gas specialists. The first licenses for exploration and production of oil were provided to foreign, 
mostly US oil companies. Due to the lack of oil legislation, all conditions and mutual obligations were established on a contractual basis. The inflow of foreign capital gave a powerful push to the development of the Norwegian oil and gas industry. The first 300 thousand tons were produced only in 1971. Today, as is known, Norway is a country that belongs to one of the world's largest oil and gas exporters. In different countries of the world, there are various forms and conditions for attracting foreign direct investment in the oil and gas industry (Table 1).

The oil and gas industry in countries where it takes precedence over the national economy, is regulated by special legislation, the most important regulations of which include: ownership concerns of oil and gas resources; issues related to the management of the development of natural resources; types of contracts/agreements: license agreement; production sharing contract; service contract; plots provided to foreign and national investors; procedures for granting licenses, permits, grants, conditions for tenders, auctions, negotiations; distribution of income (royalties, taxes, flexible scale); the issues of functioning of a state oil enterprise, its powers to represent the interests of the state within the negotiations; the transition of the relevant powers to the state oil authority during the privatization of the enterprise; dispute resolution; stability of the terms of contracts; protection of national interests: guarantee of attracting local labor, training, technology transfer; conditions for export of oil and gas, including obligations to ensure local needs; guarantee of free export of oil belonging to a foreign company.

The experience of attracting FDI in Great Britain and Norway, considering that in the deep-water areas of these countries, for several decades, oil and gas production has been actively carried out is especially important for the authors. However, the development of these resources requires significant investment, which is impossible without the creation of appropriate organizational and economic forms and legal conditions for their involvement. In order to make the extraction profitable, it is necessary to develop a model for attracting international business. The process of attracting FDI to an enterprise is realized in the form of management decisions, as well as financial, material and information flows. The interrelationships of the parties form the business environment of the process of attracting FDI, the quality of interactions of which directly affects the result of this process, which is based on communication - the process of information exchange between the parties. Thus, an enterprise that has the goal of implementing an investment project involving attracted FDI, should conduct proactive systemic activities that would attract the most suitable foreign investor and achieve certain goals. This sequence should be implemented using the achievements of economic and mathematical modeling, which is a universal tool for analyzing and accounting the main features of both production, financial and economic processes. With the help of substitute objects, one can indirectly study the functioning of real objects by applying hypotheses, analogies, mathematical tools, and methods of cognition.

Thanks to economic-mathematical models that most accurately reflect the specifications of the object of research, it becomes possible to implement such tasks as: 1) optimization of processes and tasks of managing the activities of an economic entity, considering their specific features; 2) timely response to changes in the parameters of activities, regarding goals and resource constraints for the adoption of adequate management decisions. When developing a model for selecting a foreign investor in attracting FDI, it is necessary to consider such requirements that 
TABLE 1. Forms and conditions for attracting foreign direct investment in the oil and gas industry in some countries of the world (with modifications)

TABELA 1. Formy i warunki przyciągania bezpośrednich inwestycji zagranicznych w przemyśle naftowo-gazowym w niektórych krajach świata (z modyfikacjami)

\begin{tabular}{|c|c|c|c|c|c|c|c|c|}
\hline \multirow[b]{2}{*}{ State } & \multirow{2}{*}{$\begin{array}{l}\text { Type of } \\
\text { Fiscal } \\
\text { License }\end{array}$} & \multicolumn{2}{|c|}{$\begin{array}{c}\text { Duration } \\
\text { [years] }\end{array}$} & \multirow[b]{2}{*}{$\begin{array}{c}\text { Royalty (rent) } \\
{[\%]}\end{array}$} & \multirow[b]{2}{*}{ Bonus } & \multirow{2}{*}{$\begin{array}{l}\text { Recompense } \\
\text { of costs for } \\
\text { PSAs } \\
{[\%]}\end{array}$} & \multirow{2}{*}{$\begin{array}{c}\text { Charges on } \\
\text { the internal } \\
\text { market }\end{array}$} & \multirow{2}{*}{$\begin{array}{c}\text { State } \\
\text { participation } \\
{[\%]}\end{array}$} \\
\hline & & $\begin{array}{l}\text {.0 } \\
. \frac{\pi}{0} \\
\frac{0}{0} \\
\frac{0}{x} \\
0\end{array}$ & 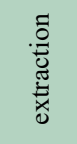 & & & & & \\
\hline CIS & $\begin{array}{c}\text { LS + PSA } \\
\text { (does not } \\
\text { work) }\end{array}$ & $\begin{array}{l}\text { up to } \\
20\end{array}$ & 20 & $\begin{array}{l}\text { regulated } \\
\text { by budget } \\
\text { legislation }\end{array}$ & $\begin{array}{c}\text { on PSA on } \\
\text { contract } \\
\text { terms }\end{array}$ & 100 & $\begin{array}{c}\text { on PSA on } \\
\text { contract } \\
\text { terms }\end{array}$ & \\
\hline Algeria & PSA & $4+2$ & 12 & $\begin{array}{l}\text { floating } \\
12.25-20\end{array}$ & $\begin{array}{c}\text { for } \\
\text { permission } \\
\text { to explore }\end{array}$ & - & $\begin{array}{c}\text { on gas on } \\
\text { contractual } \\
\text { terms }\end{array}$ & $\begin{array}{c}51 \text { of } \\
\text { explored } \\
\text { reserves }\end{array}$ \\
\hline Argentina & LS & $3+6$ & 20 & floating 5-12 & - & - & there are & $\begin{array}{c}\text { 15-50 of oil } \\
\text { sales }\end{array}$ \\
\hline France & LS & $5+10$ & $5+10$ & $\begin{array}{l}\text { floating 0-12 } \\
\text { oil; 5 - gas }\end{array}$ & - & 100 & no & no \\
\hline Egypt & $\mathrm{LS}+\mathrm{PSA}$ & 8 & 20 & $0-10$ & & $\begin{array}{l}\text { 30-land; } \\
\text { 40-shelf }\end{array}$ & no & no \\
\hline Canada & LS & & & floating, $0-50$ & $\begin{array}{l}\text { there is } \\
\text { in the } \\
\text { province } \\
\text { of Alberta }\end{array}$ & - & there are & \\
\hline China & SPA & 30 & $7+15$ & $\begin{array}{c}\text { floating } 0-12.5 \\
\text { oil; gas: shelf } \\
0-3 \text {; land } \\
0-12.5 . \text { Pseudo } \\
\text { royalty }-5\end{array}$ & - & $50-62.5$ & No & $\begin{array}{c}\text { up to } 51 \\
\text { of oil sales }\end{array}$ \\
\hline $\begin{array}{l}\text { Russian } \\
\text { Federation }\end{array}$ & $\mathrm{LS}+\mathrm{SPA}$ & & 25 & $\begin{array}{c}\text { absent, } 13.5-19 \\
\text { single tax }\end{array}$ & - & 50 & there are & $\begin{array}{c}\text { up to } 51 \\
\text { of oil sales }\end{array}$ \\
\hline Syria & SPA & & & 11 & there is & 35 & no & no \\
\hline USA & LS & & & floating $0.5-10$ & & there is & no & 60 \\
\hline $\begin{array}{l}\text { Great } \\
\text { Britain }\end{array}$ & LS & 18 & - & $\begin{array}{c}\text { no, a } 75 \text { tax on } \\
\text { oil profits }\end{array}$ & no & 100 & $\begin{array}{l}60 \text { months } \\
10 \% \text { of the } \\
\text { market price } \\
\text { for } 25 \% \text { of oil }\end{array}$ & no \\
\hline Norway & LS & 30 & - & $\begin{array}{c}\text { no, } 30 \\
\text { special tax }\end{array}$ & - & 100 & no & $\begin{array}{c}80 \text { company } \\
\text { Statoil }\end{array}$ \\
\hline
\end{tabular}

Source: own study. 
are common to the creation of all economic and mathematical models, namely: the independence of results from the object interpretation of model elements; content of the main features and properties of the process of its development; accumulation of knowledge about the object of modeling for the study of cause and effect regularities in the direction from particulars to generals. In addition, the development of the above-mentioned model will be carried out through the following successive stages: 1) the definition of the problem and the statement of the main problem; 2) creation of a conceptual model for the development of the FDI attraction system and its structural and functional description; 3 ) checking the model for the adequacy of the results; 4) interpretation of results in basic terms of the subject domain; 5) formulation of opinions and recommendations.

Studying one side of an object that is modeled, it becomes necessary to abandon some other. Therefore, it should be borne in mind that any model characterizes the original object only in a strictly defined foreshortening, and this makes it possible to construct various specifications of the model with different degrees of detail. The most important point of the process of creating a model, which determines the value of the results obtained, is the statement of the problem. Since the activity in the management of the process of foreign direct investment belongs to the party that initiates it, this study will only consider the case when the initiator is the company that seeks to attract FDI. Thus, Rosneft, for the investor's interest in cooperation at the Sakhalin- 8 deposit (a cross-border resource with Japan), developed technical and economic proposals for the technical organization of the Vladivostok-LNG plant. It is assumed that Rosneft has sufficient resources (tangible assets, knowledge) to find a business partner (the Chinese National Oil Company), and that access to the information about the investment opportunities of the enterprise is limited due to the specificity of investments in this sphere (Fig. 1).

As already noted, the key areas of activity aimed at attracting FDI, which directly affect the result of the system of attracting FDI to the enterprise, are the technical and social areas. It should be noted that the accentuation of these areas does not detract from the importance of the role of others. However, in the situation in which an enterprise starts to search for foreign investors in order to attract FDI, it is assumed that the ensure state in other areas is already optimal, and their improvement is possible at the expense of the investor's resources, and this is caused by the process of attracting FDI to the enterprise. At the first stage of choosing and attracting a direct foreign investor, it is necessary to evaluate the level of functioning of the system for attracting FDI to the enterprise in the technical and social areas, that is, the effectiveness of managing activities aimed at attracting FDI. This will allow to rank and select the most suitable type of foreign direct investor in order to achieve the objectives of the enterprise through the maximum satisfaction of the needs of a foreign direct investor during the duration of the investment project.

The direction of the development of the system of attracting FDI to enterprises, reflecting the activities of the enterprise, is aimed at studying the capital market in order to attract FDI for the implementation of a certain investment project by creating demand for it. It is cross-cutting in all three states of the system: preparation for attracting FDI; readiness to attract FDI; attracting FDI. The level of compliance with the direction of development of the system for attract- 


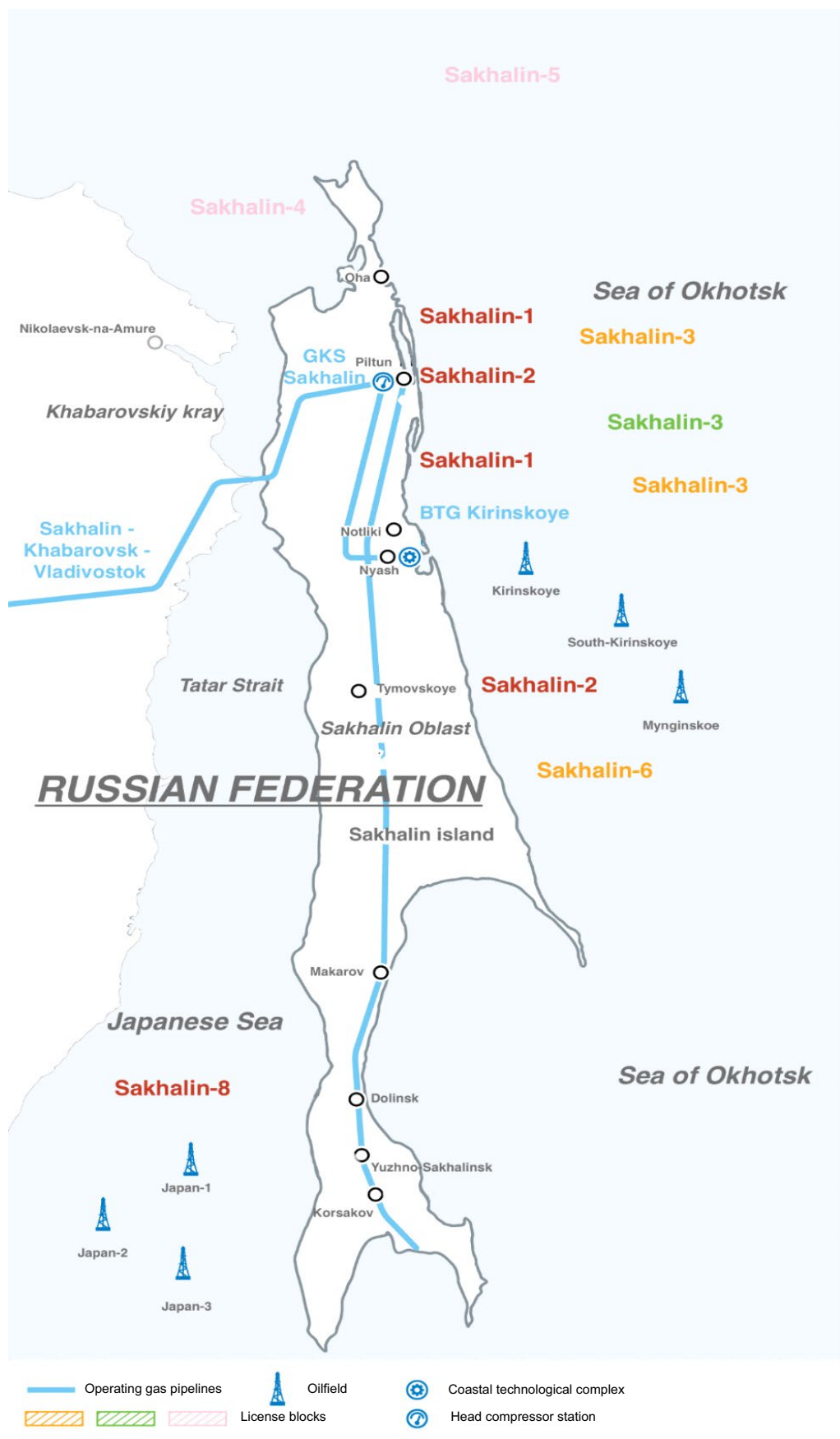

Fig. 1. Perspective zones of business interaction between Russia and Japan in the Sakhalin-8 project Source: own study

Rys. 1. Perspektywiczne strefy interakcji biznesowej między Rosją a Japonią w projekcie Sachalin-8 
ing FDI to enterprises in the constructed model is denoted by and is calculated using the following formula (1):

$$
L^{1}=\left\langle L_{1}^{1}, L_{2}^{1}, L_{3}^{1}\right\rangle=\sum_{i=1}^{3} \alpha_{i}^{1} L_{i}^{1}, \sum_{i}^{3} \alpha_{i}^{1}=1
$$

where:

$L^{1}-$ a level of compliance with the direction of development of the foreign investor attraction system, part. units $[0 ; 1]$,

$L_{1}^{1}$ - an indicator of the state of the system "Preparation for attracting FDI",

$L_{2}^{1}$ - an indicator of the state of the system "Readiness to attract FDI",

$L_{3}^{1}-\quad$ an indicator of the state of the system "Attracting FDI",

$i$ - the serial number of the system state in the direction $i=1,3$,

$\alpha_{i}^{1}-\quad$ weight coefficient of the corresponding state of the system for directions at the time of the decision:

$$
\alpha_{i}^{1}>0, \sum_{i}^{3} \alpha_{i}^{1}=1
$$

Each of the considered states of the system within the framework of observing the direction is characterized by various parameters, the number and content of which can vary depending on the specifics of the investment project, the direction of the enterprise, its size, spheres of activity, and so on. Considering the following parameters that determine the level of compliance with the direction of development of the system for attracting FDI to enterprises in each state of the system is proposed. So, being in a state of "Preparation for attracting FDI", the $L_{1}^{1}$, parameters characterizing compliance with the direction are as follows: completeness of completed tasks required to attract FDI; geographical coverage of the FDI market in the search for a foreign direct investor; the size of the selected estimate for attracting FDI; network interaction of the enterprise with other organizations (business associations, chambers of commerce and industry, local government); business transparency.

The next state, in which the system of attracting FDI to enterprises passes is the "Readiness to attract FDI". In it, observance of the $L_{2}^{1}$ direction is characterized by such parameters: reputation of the enterprise; dynamics of contact base development. The final parameter characterizing the compliance of the direction in the state of the "Attracting FDI" system is the planned volume of attracting FDI. Thus, compliance with the direction in each state of the system is characterized by a different number of parameters. This can be reflected using the following formula (3):

$$
L_{i}^{1}=\sum_{j=1}^{n_{i}^{1}} \beta_{i j}^{1} L_{i j}^{1}
$$

where:

$\beta_{i j}^{1}-$ is the weight coefficient of the $j$-th parameter in the $i$-th state of the $n$-direction system at the moment of making the decision, 
$\beta_{i j}^{1}>0, \sum_{j=1}^{n} \beta_{i j}^{1}=1$ for $\forall i=\overline{1,3} L_{i j}^{1}-$ the value of the $j$-th parameter in the $i$-th state of the direction system, $j=\overline{1, n_{i}^{1}}$.

However, different parameters characterizing the observance of the development direction of the system in each state of the system are affected by a different number of qualitative and quantitative factors of the external and internal environment of the enterprise, which is reflected by the following formula (4):

$$
L_{i j}^{1}=\sum_{r=1}^{R_{j}^{1}} \gamma_{i j r}^{1} L_{i j r}^{1}
$$

where

$\gamma_{i j r}^{1} \quad$ - is the weight coefficient of the $r$-th influence factor on the $j$-th parameter in the $i$-th state of the direction system at the moment of decision making:

$$
\gamma_{i j r}^{1}>0, \sum_{r=1}^{R} \gamma_{i j r}^{1}=1 \text { for } \forall\left\{\begin{array}{l}
i=\overline{1.3} \\
j=\overline{1 . n}
\end{array}\right.
$$

where

$L_{i j r}^{1} \quad$ - the value of the $r$-th influence factor on the $j$-th parameter in the $i$-th state of the direction system, $r=\overline{1, R_{j}^{1}}$.

The second direction of the development of the system of attracting FDI to enterprises is the social direction, which reflects the direction of the company's efforts to minimize the influence of uncertainty on the process of making an investment decision on the part of a foreign investor for the implementation of a certain investment project with the mediation of FDI. Its functioning implies the activation of human capital at the enterprise (a project team whose functional responsibility is direct attraction of FDI) with the aim of establishing quality interaction with a foreign investor at all stages of the FDI attracting process.

\section{Conclusions}

Thus, in the presented three-level model the first level is institutional, defined by regional and international agreements between cities, regions of the state, and sub-regions of the continent. This determines the second necessary level, which is called organizational or infrastructural. This stage is characterized by the existence of legislation and economic security in a specific state, and the possibility of attracting subjects of international business. The level of the subsequent type is a complex phenomenon. It is determined by the development of a model that allows for predicting the possibility of realizing the interests of subjects of international business. 
The analysis of various organizational and economic forms of relations of foreign companies with the state in cross-border regions shows that their modern modifications are quite flexible and can lead to approximately similar results of the effectiveness of receiving economic rent by the state. But at the same time, due to the transparency of the economic mechanism for collecting PSA fiscal payments and greater "independence" from general legislation, up to today, it seems more acceptable for countries that are developing. The successful functioning of the concession system requires a much deeper study of both fiscal regimes in the territory of such countries and the solution of numerous legal issues of mining legislation. The greatest positive effect for the host country is given by foreign direct investment since they represent long-term investments, are oriented primarily to the strategic advantages of the host country, and are not very influenced by short-term crisis factors. Apart from this, FDI is associated with the transfer of best practices, new technologies, management practices, and market technologies to the country, which leads to an increase in the overall level of competitiveness of the economy in the host state.

\section{References}

Akhundjanov, S.B. and MuÑoz-García, F. 2019. Transboundary natural resources, externalities, and firm preferences for regulation. Environmental and Resource Economics 73(1), pp. 333-352, DOI: 10.1007/ s10640-018-0265-5.

AL-FARAJ, F.A.M. and Tigkas, D. 2016. Impacts of multi-year droughts and upstream human-induced activities on the development of a semi-arid transboundary basin. Water Resources Management 30(14), pp. 5131-5143, DOI: /10.1007/s11269-016-1473-9.

ALI, S.H. and ZIA, A. 2017. Transboundary data sharing and resilience scenarios: Harnessing the role of regional organizations for environmental security. [In:] Adeel, Z. and Wirsing, R.G. eds. Imagining Industan: Overcoming Water Insecurity in the Indus Basin. Cham: Springer International Publishing, pp. 121-139.

Barbakov et al. 2019 - Barbakov, O.M., Gabisheva, L.K. and Kretova, A.Y. 2019. International regulation of environmental management in the Arctic zone. Journal of Environmental Management and Tourism 10(5), pp. 1020-1028, DOI: 10.14505/jemt.v10.5(37).09.

Bolgov et al. 2016 - Bolgov, M.V., Demin, A.P. and Shatalova, K.Y. 2016. Institutional, regulatory, and managerial aspects of the development of transboundary water bodies and streams in Russia (Institutsional'nyye, normativno-pravovyye i upravlencheskiye aspekty ispol'zovaniya transgranichnykh vodnykh ob"yektov Rossii). Vodnyye Resursy - Water Resources 43(4), pp. 711-717, DOI: 10.1134/ s0097807816040047 (in Russian).

Boоth et al. 2020 - Bоотн, L., Fleming, K., Abad, J., Schueller, L.A., Leone, M., Scolobig, A. and BaILLS, A. 2020. Simulating synergies between climate change adaptation and disaster risk reduction stakeholders to improve management of transboundary disasters in Europe. International Journal of Disaster Risk Reduction 49, 101668, DOI: 10.1016/j.ijdrr.2020.101668.

CARR, C.J. 2017. Transboundary survival systems: A profile of vulnerability river basin development and human rights in eastern Africa - a policy crossroads. Cham: Springer International Publishing.

Degefu et al. 2016 - Degefu, D.M., He, W., YuAn, L. and ZhaO, J.H. 2016. Water allocation in transboundary river basins under water scarcity: A cooperative bargaining approach. Water Resources Management 30(12), pp. 4451-4466, DOI: 10.1007/s11269-016-1431-6. 
EARLE, A. and Neal, M.J. 2017. Inclusive transboundary water governance. [In:] Karar, E. ed. Freshwater Governance for the $21^{\text {st }}$ Century. Cham: Springer International Publishing, pp. 145-158.

Giordano et al., 2016 - Giordano, M., Suhardiman, D. and Peterson-Perlman, J. 2016. Do hydrologic rigor and technological advance tell us more or less about transboundary water management? International Environmental Agreements: Politics, Law and Economics 16(6), pp. 815-831, DOI: 10.1007/ s10784-015-9297-2.

Hashemolhosseini, B. 2020. United States: Decoupling the economy from natural resource degradation: Enhancing the role of the environmental impact assessment. Environmental Policy and Law 50(1-2), pp. 135-147, DOI: 10.3233/EPL-200197.

He et al. 2017 - He, D., Chen, X., Ji, X., Hu, J., Bao, A., Zhong, R., Feng,Y., LI, Y., Huang, Y. and JIAPAER, G. 2017. International rivers and transboundary environment and resources. [In:] The Geographical Sciences During 1986-2015: From the Classics To the Frontiers. Singapore: Springer Singapore, pp. 469-480.

Healy et al. 2019 - Healy, N., Stephens, J.C. and Malin, S.A. 2019. Embodied energy injustices: Unveiling and politicizing the transboundary harms of fossil fuel extractivism and fossil fuel supply chains. Energy Research and Social Science 48, pp. 219-234, DOI: 10.1016/j.erss.2018.09.016.

Holmatov et al. 2016 - Holmatov, B., Lautze, J. and Kazbekov, J. 2016. Tributary-level transboundary water law in the Syr Darya: overlooked stories of practical water cooperation. International Environmental Agreements: Politics, Law and Economics 16(6), pp. 873-907, DOI: 10.1007/s10784015-9308-3.

Li et al. 2016 - Li, B., TAN, G. and ChEN, G. 2016. Generalized uncooperative planar game theory model for water distribution in transboundary rivers. Water Resources Management 30(1), pp. 225-241, DOI: 10.1007/s11269-015-1158-9.

LiM, M. 2016. Governance criteria for effective transboundary biodiversity conservation. International Environmental Agreements: Politics, Law and Economics 16(6), pp. 797-813, DOI: 10.1007/s10784-015-9296-3.

MADANI, K. 2020. How international economic sanctions harm the environment. Earth's Future 8(12), e2020EF001829, DOI: 10.1029/2020EF001829.

MASOn et al. 2017 - MASON, C.F., UMANSKAYA, V.I. and BARBIER, E.B. 2017. Trade, transboundary pollution, and foreign lobbying. Environmental and Resource Economics 70, pp. 223-248, DOI: 10.1007/ s10640-017-0118-7.

Mason et al. 2020 - Mason, N., Ward, M., Watson, J.E.M., Venter, O. and Runting, R.K. 2020. Global opportunities and challenges for transboundary conservation. Nature Ecology and Evolution 4(5), pp. 694-701, DOI: 10.1038/s41559-020-1160-3.

NAŁĘCZ, T. and PuRI, S. 2012. Implementation of legal mechanisms to strengthen the process of transboundary aquifer resources management. [In:] Nałęcz, T. ed. Transboundary Aquifers in the Eastern Borders of The European Union. NATO Science for Peace and Security Series C: Environmental Security. Dordrecht: Springer Netherlands, pp. 1-6.

Pétré et al. 2016 - Pétré, M.-A., Rivera, A., Lefebvre, R., Hendry, M.J. and Folnagy, A.J.B. 2016. A unified hydrogeological conceptual model of the Milk River transboundary aquifer, traversing Alberta (Canada) and Montana (USA). Hydrogeology Journal 24(7), pp. 1847-1871, DOI: 10.1007/s10040-016-1433-8.

Rai et al. 2017a - Rai, S.P., Wolf, A.T., Sharma, N. and Tiwari, H. 2017. Hydropolitics in transboundary water conflict and cooperation. [In:] Sharma, N. ed. River System Analysis and Management. Singapore: Springer Singapore, pp. 353-368.

Rai et al. 2017b - RaI, S.P., Young, W. and Sharma, N. 2017. Risk and opportunity assessment for water cooperation in transboundary river basins in South Asia. Water Resources Management 31(7), pp. 2187-2205, DOI: 10.1007/s11269-017-1637-2. 
REYNOLDS, J.L. 2019. An economic analysis of international environmental rights. International Environmental Agreements: Politics, Law and Economics 19(6), pp. 557-575, DOI: 10.1007/s10784-019-09454-7.

Salmoral et al. 2019 - Salmoral, G., SchaAp, N.C.E., Walschebauer, J. and Alhajaj, A. 2019. Water diplomacy and nexus governance in a transboundary context: In the search for complementarities. Science of the Total Environment 690, pp. 85-96, DOI: 10.1016/j.scitotenv.2019.06.513.

SCHIFF, J.S. 2017. The evolution of Rhine river governance: historical lessons for modern transboundary water management. Water History 9, pp. 279-294, DOI: 10.1007/s12685-017-0192-3.

SiNGH, N. 2016. Human right to water in transboundary water regimes. [In:] Singh, N. ed. The Human Right to Water: From Concept to Reality. Cham: Springer International Publishing, pp. 205-221.

TANG et al. 2016 - TANG, L., Gui, L., SHAO, G., WANG, L. and SHI, L. 2016. Practice and research progress on ecosystem conservation in transboundary areas. Chinese Geographical Science 26(1), pp. 109-116, DOI: $10.1007 / \mathrm{s} 11769-015-0761-2$.

Thornton et al. 2020 - Thornton, D., Branch, L. and Murray, D. 2020. Distribution and connectivity of protected areas in the Americas facilitates transboundary conservation. Ecological Applications 30(2), DOI: 10.1002/eap.2027.

TILLEARD, S. and FoRD, J. 2016. Adaptation readiness and adaptive capacity of transboundary river basins. Climatic Change 137(3), pp. 575-591, DOI: 10.1007/s10584-016-1699-9.

Oksana D. HnatKovych, Volodymyr V. Hoblyk, Olena V. Lazarieva, Vasyl V. Burba, Yevhenii Ye. Hrechin

\section{Regulacyjne aspekty zagospodarowania i wykorzystania zasobów energetycznych w strefach transgranicznych przez biznes międzynarodowy}

\section{Streszczenie}

W artykule przedstawiono aspekty prawnej charakterystyki i regulacji traktowania zasobów naturalnych, które są objęte wspólną dzierżawą dwóch lub więcej państw. O nowatorstwie naukowym opracowania przesądza fakt, który ukazuje aspekty interakcji międzynarodowych i kształtowania się praktyki legislacyjnej regulacji korzystania z zasobów naturalnych nie tylko w zakresie regulacji państwowych i prawnych, ale także w kontekście partnerstwa publiczno-prywatnego. Waga zagadnienia polega na tym, że głównym problemem wykorzystania takich zasobów energetycznych jest właściwe sformułowanie i odpowiednia realizacja przepisów międzynarodowych w zakresie przedsięwzięć gospodarczych. Celem artykułu jest zbadanie, w jaki sposób przedstawiciele biznesu międzynarodowego mogą realizować w ramach współpracy transgranicznej projekty wydobywania zasobów naturalnych w obszarach transgranicznych w różnych warunkach współpracy międzynarodowej. W pracy posłużono się metodami statystyki matematycznej, metodami analizy historycznej i prawnej. Przedstawiono trójpoziomowy model działania. Na pierwszym etapie określa się możliwość współpracy, następnie tworzy jej ramy prawne i regulacyjne, 
i na kolejnym etapie określa się instrumenty o charakterze ekonomiczno-prawnym, które można wdrożyć w tym zakresie. Ostatnim elementem przedstawionego modelu jest znalezienie możliwości zainwestowania w rozwój pozyskiwania zasobów energetycznych na zasadzie parytetu, a także tworzenie zintegrowanego środowiska, które determinuje możliwość integracji podmiotów biznesu międzynarodowego w otoczeniu gospodarczym.

SŁowA KLUCzowE: współpraca transgraniczna, ekosystem, zarządzanie zasobami, koncesja, przyciąganie bezpośrednich inwestycji zagranicznych (BIZ) 
